PENETRATE-LEACH DISSOLUTION OF ZIRCONIUM-CLAD URANIUM AND URANIUM DIOXIDE FUELS

H. D. HARMON

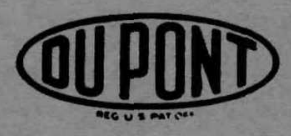

SAVANNAH RIVER LABORATORY AIKEN, SOUTH CAROLINA 29801 
This report was prepared as an account of work sponsored by the United States Govarnment. Neither the United States nor the United States Energy Research and Development Administration, nor any of their contractors, subcontractors, or their employees, makes any warranty, express or implied, or assumes any legal liability or responsibility for the accuracy, completeness or usefulness of any information, apparatus, product or process disclosed, or represents that its use would not infringe privately owned rights.

Printed in the United States of America

Available from

National Technical Information Service

U.S. Department of Commerce

5285 Port Royal Road

Springfield, Virginia 22161

Price: Printed Copy $\$ 3.50$; Microfiche $\$ 2.25$ 


\section{DISCLAIMER}

This report was prepared as an account of work sponsored by an agency of the United States Government. Neither the United States Government nor any agency Thereof, nor any of their employees, makes any warranty, express or implied, or assumes any legal liability or responsibility for the accuracy, completeness, or usefulness of any information, apparatus, product, or process disclosed, or represents that its use would not infringe privately owned rights. Reference herein to any specific commercial product, process, or service by trade name, trademark, manufacturer, or otherwise does not necessarily constitute or imply its endorsement, recommendation, or favoring by the United States Government or any agency thereof. The views and opinions of authors expressed herein do not necessarily state or reflect those of the United States Government or any agency thereof. 


\section{DISCLAIMER}

Portions of this document may be illegible in electronic image products. Images are produced from the best available original document. 


\title{
PENETRATE-LEACH DISSOLUTION OF ZIRCONIUM-CLAD URANIUM AND URANIUM DIOXIDE FUELS
}

\author{
by \\ H. D. Harmon
}

Approved by

M. L. Hyder, Research Manager

Separations Chemistry Division

Publication Date: October 1976

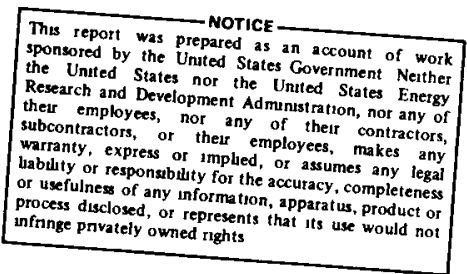

E. I. DU PONT DE NEMOURS AND COMPANY SAVANNAH RIVER LABORATORY AIKEN, SOUTH CAROLINA 29801

PREPARED FOR THE U S. ENERGY RESEARCH AND DEVELOPMENT ADMINISTRATION UNDER CONTRACT AT(07-2) 1 


\section{ABSTRACT}

A new decladding-dissolution process was developed for zirconium-clad uranium metal and $\mathrm{UO}_{2}$ fuels. The proposed penetrate-leach process consists of penetrating the zirconium

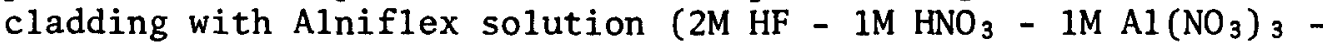
$0.1 \mathrm{M} \mathrm{K}_{2} \mathrm{Cr}_{2} \mathrm{O}_{7}$ ) and of leaching the exposed core with $10 \mathrm{M} \mathrm{HNO}_{3}$. Undissolved cladding pieces are discarded as solid waste. $\mathrm{Pe}$ riodic $\mathrm{HF}$ and $\mathrm{HNO}_{3}$ additions, efficient agitation, and in-line zirconium analyses are required for successful control of $\mathrm{ZrF}_{4}$ and/or $\mathrm{AlF}_{3}$ precipitation during the cladding-penetration step. Preliminary solvent extraction studies indicated complete recovery of uranium with 30 vol \% tributyl phosphate (TBP) from both Alniflex solution and blended Alniflex- $\mathrm{HNO}_{3}$ leach solutions. With 7.5 vol \% TBP, high extractant/feed flow ratios and low scrub flows are required for satisfactory uranium recovery from Alniflex solution. Modified waste-handling procedures may be required for Alniflex waste, because it cannot be evaporated before neutralization and large quantities of solids are generated on neutralization. The effect of unstable UZr $r_{3}$ (epsilon phase of uranium-zirconium system) on the safety of penetrate-leach dissolution was investigated. 


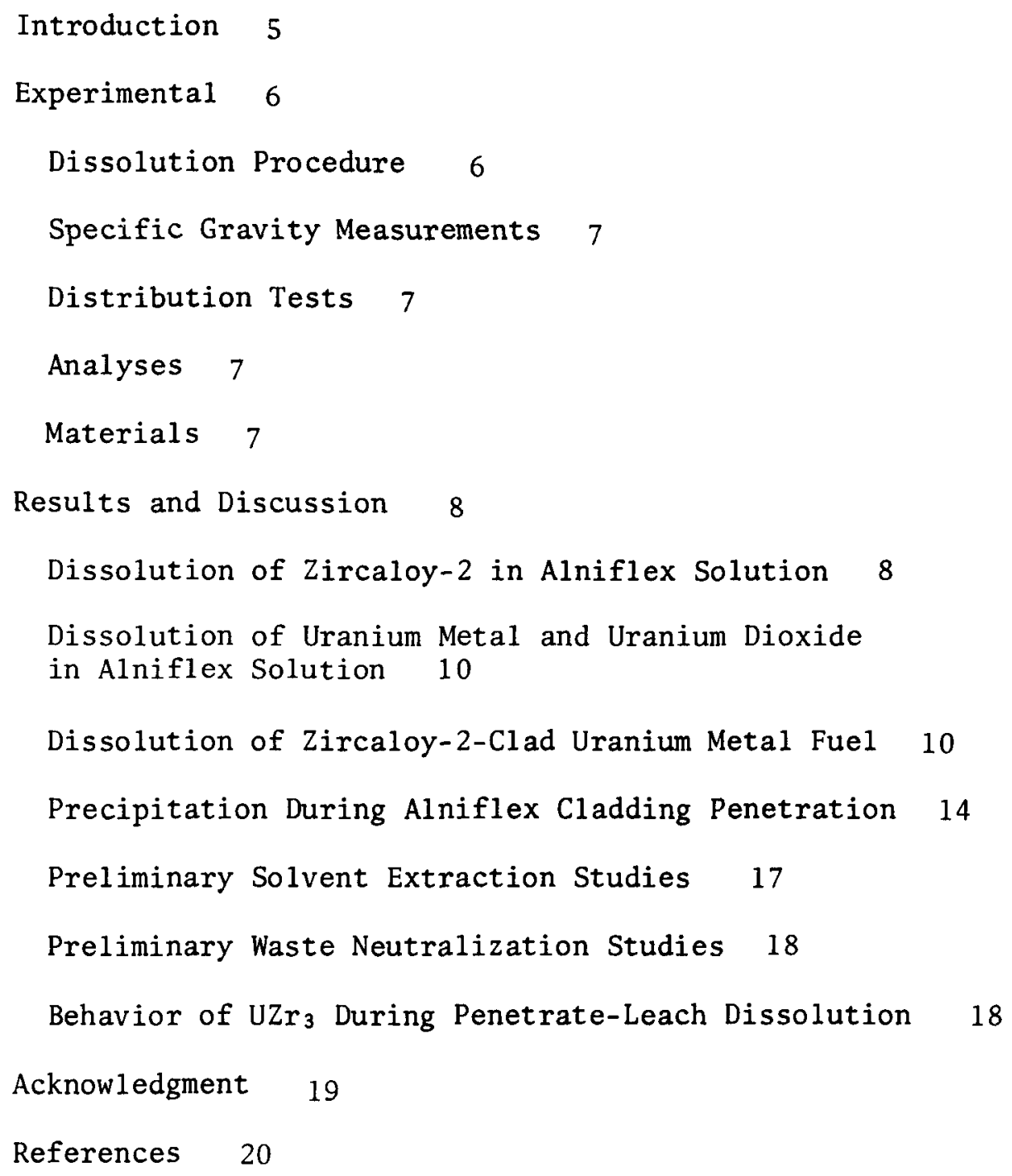




\section{LIST OF TABLES}

1 Corrosion of 304L Stainless Steel in

$\mathrm{HF}-\mathrm{HNO}_{3}-\mathrm{Al}\left(\mathrm{NO}_{3}\right)_{3}$ Solution 8

2 Summary of Precipitation During Cladding Penetration

of Zircaloy-2-Clad Uranium Metal Fue1 15

3 Extraction of Uranium from Alniflex and Blended Alniflex- $-\mathrm{HNO}_{3}$ Solutions 17

\section{LIST OF FIGURES}

1 Alniflex Dissolution of Zircaloy-2 9

2 Alniflex Dissolution of Uranium Metal and Uranium Dioxide 11

3 Zircaloy-2-Clad Uranium Metal Fuel Piece During Penetrate-Leach Dissolution 12

4 Penetrate-Leach Dissolution of Zircaloy-2-Clad Uranium Metal Fuel 13

5 Specific Gravity of Alniflex Solutions 16

6 Behavior of $\mathrm{UZr}_{3}$ During Penetrate-Leach Dissolution of Zircaloy-2-Clad Uranium Metal Fue1 19 


\section{PENETRATE-LEACH DISSOLUTION OF ZIRCONIUM-CLAD URANIUM AND URANIUM DIOXIDE FUELS}

\section{INTRODUCTION}

A new decladding-dissolution process was developed for zirconium-clad uranium metal and $\mathrm{UO}_{2}$ fuels as an alternative to Zirflex, ${ }^{1}$ electrolytic dissolution, ${ }^{2}$ and shear-leach processing. ${ }^{3}$ The new process, called penetrate-leach, is an adaptation of the Alniflex process ${ }^{4}$ developed for dissolving zirconium-clad uraniumzirconium alloy fuels in stainless steel equipment. Alniflex dissolvent is used to penetrate the cladding and expose regions of the uranium or $\mathrm{UO}_{2}$ core for dissolution in nitric acid. The proposed process consists of the following steps:

- Fuel is charged to the dissolver in perforated stainless steel baskets.

- A sufficient amount of Alniflex ${ }^{4}$ dissolvent (initially. $\left.2 \mathrm{M} \mathrm{HF}-1 \mathrm{M} \mathrm{HNO}{ }_{3}-1 \mathrm{M} \mathrm{Al}\left(\mathrm{NO}_{3}\right)_{3}-0.1 \mathrm{M} \mathrm{K} \mathrm{CCr}_{2} \mathrm{O}_{7}\right)$ is added to partially dissolve the zirconium cladding and expose the core. Attack on the cladding is inhomogeneous, and only a portion must be dissolved to expose the core. A portion of exposed core also dissolves during this step.

- Alniflex cladding-penetration solution is removed from the dissolver, and the remaining core is dissolved in nitric acid.

- Undissolved cladding is discarded as solid waste.

- Two uranium-bearing solutions are processed (either separately or as a combined solution) by the Purex solvent extraction process (30 vol \% TBP) or by the Savannah River Plant (SRP) enriched uranium process ( 7.5 vol $\%$ TBP), depending on the ${ }^{235} \mathrm{U}$ content of the fuel and the total uranium concentration.

The penetrate-leach process combines several advantages of the Alniflex and shear-leach processes. First, the Alniflex cladding-penetration step is compatible with 304L stainless steel process equipment. Second, dissolution is entirely chemical; therefore maintaining an expensive shear machine in a remote area is not required. Third, liquid waste volumes and solid contents are less than those in processes involving total dissolution of cladding because only a portion of cladding is dissolved; undissolved cladding pieces (hulls) are discarded as solid waste. Finally, $\mathrm{UZr}_{3}$ intermetallic compound, which may be formed at the core-cladding interface of zirconium-clad uranium metal and $\mathrm{UO}_{2}$ 
fuels during fabrication and/or irradiation, cannot accumulate in the dissolver in hazardous quantities. $\mathrm{UZr}_{3}$ dissolves in fluoride-containing reagents, such as Alniflex dissolvent, but it is insoluble in nitric acid. ${ }^{5,6}$ Thus, $\mathrm{UZr}_{3}$ not dissolved by the cladding-penetration step is removed with the spent hulls as in the shear-leach process, but in significantly smaller amounts.

\section{EXPERIMENTAL}

\section{Dissolution Procedure}

Preliminary dissolution of Zircaloy-2, uranium, and $\mathrm{UO}_{2}$ were conducted with $100 \mathrm{ml}$ of Alniflex dissolvent in 250-m1 roundbottomed flasks equipped with a condenser and thermometer. No mechanical stirring was provided, because such agitation is not used in plant equipment. The metal pieces and $\mathrm{UO}_{2}$ pellet were removed periodically for weight loss determinations. In accordance with the Alniflex procedure, ${ }^{4}$ concentrated HF was added every $2 \mathrm{hr}$ after $>40 \%$ of the Zircaloy-2 dissolved to increase the total fluoride concentration by $0.5 \mathrm{M}$ and to prevent precipitation of $\mathrm{ZrF}_{4}$ and $\mathrm{AlF}_{3}$. $\mathrm{HF}$ also was added during the uranium and $\mathrm{UO}_{2}$ dissolutions to measure the effect of HF concentration on the fuel dissolution rate.

Penetrate-1each dissolutions were demonstrated with 1 - to 4-inch sections of unirradiated Zircaloy-2-clad uranium metal fuel. The bare, cut ends of the fuel were protected from Alniflex dissolvent by "Teflon"* end caps. Tests were conducted in a 2-1iter "Pyrex"** dissolver equipped with a condenser and thermometer. The temperature was maintained at $70-75^{\circ} \mathrm{C}$; in some tests, the solution was agitated by an air sparge. The zirconium dissolution rate was determined by periodic measurements of the weight of the fuel piece and/or by measurement of solution specific gravity. $\mathrm{HF}$ and $\mathrm{HNO}_{3}$ were added periodically during the cladding-penetration step to prevent precipitation of zirconium, aluminum, or uranium. After the cladding was sufficiently penetrated, the remaining core was leached with boiling $10 \mathrm{M} \mathrm{HNO}_{3}$. Two leaching steps were used in some tests to minimize the volume of $\mathrm{HNO}_{3}$ required and to decrease the time required for complete leaching.

Any precipitates formed during the cladding-penetration step were filtered, washed, dried, and analyzed by spark source mass spectrometry and $x$-ray diffraction.

* Trademark of Du Pont for fluorocarbon resin.

** Trademark of Corning Glass Works. 


\section{Specific Gravity Measurements}

Alniflex solutions containing 2 to $3 \mathrm{M} \mathrm{HF}$ and 0 to 60 grams of zirconium per liter were prepared. Specific gravities of these solutions were measured at $25,40,55$, and $70^{\circ} \mathrm{C}$ in $5-$ or $10-\mathrm{ml}$ volumetric flasks. The flasks were calibrated to $\pm 0.002 \mathrm{ml}$ at $25^{\circ} \mathrm{C}$ with triply distilled water. The cubical coefficient of expansion of borosilicate glass was assumed to be $0.000025^{\circ} \mathrm{C}^{-1}$ for calculations of volume corrections for $40-70^{\circ} \mathrm{C} .{ }^{7}$ During dissolution tests, dissolvent specific gravities were measured with standard hydrometers.

\section{Distribution Tests}

Distribution coefficients were measured for extraction of uranium from Alniflex solution, or a 2 to 1 blend of Alniflex solution and $\mathrm{HNO}_{3}$ leach solution, into 30 and 7.5 vol $\%$ TBP in $\mathrm{n}$-paraffin diluent. Twenty $\mathrm{ml}$ each of the organic and aqueous phases were equilibrated by shaking $\sim 15$ min at $25^{\circ} \mathrm{C}$. After equilibration, samples of each phase were analyzed for uranium.

\section{Analyses}

Total fluoride was measured with a specific fluoride ion electrode (Orion Model 94-09*). Phosphoric acid was used to complex cations and free the fluoride for detection. ${ }^{8}$ Acid was determined by $\mathrm{pH}$ titration with $\mathrm{KF}$ added to complex hydrolyzable cations. Zirconium concentrations were calculated from weight loss measurements and also measured in some cases by atomic absorption spectrophotometry. Aqueous uranium was determined colorimetrically as the uranyl thiocyanato complex; organic uranium was determined similarly after stripping into $0.5 \mathrm{M}$ $\mathrm{Na}_{2} \mathrm{CO}_{3}$ solution.

\section{Materials}

For preliminary tests of zirconium dissolution, short sections of 30-mil-thick Zircaloy-2 tubing were oxidized by heating in steam at $400^{\circ} \mathrm{C}$ and 950 to 1500 psig for 2 days. The oxidized pieces were fitted with a "Teflon" insert to prevent attack on their interior surface. Depleted uranium metal and a $\mathrm{UO}_{2}$ pellet (density of 9.7 $\mathrm{g} / \mathrm{cm}^{3}$ ) were obtained from fuel fabrication studies at Savannah River Laboratory (SRL). The Zircaloy-2-clad uranium metal fuel

* Orion Research Incorporated, Cambridge, Massachusetts. 
element was a coextruded tube intended for the now decommissioned Heavy Water Components Test Reactor (HWCTR). ${ }^{9}$ The tube was cut into 1- to 4-inch sections for dissolving tests.

Tributyl phosphate (TBP) and n-paraffin diluent $\left(\mathrm{C}_{13}-\mathrm{C}_{14}\right.$ hydrocarbons with an average molecular weight of 191) were obtained from SRP. All other chemicals used were reagent grade.

\section{REŠULTS AND DISCUSSION}

\section{Dissolution of Zircaloy-2 in Alniflex Solution}

Dissolving tests simulating cladding penetration of a Zircaloy-2clad fuel rod indicated rapid dissolution in boiling Alniflex solution (Figure 1). The dissolution rate decreased significantly when the temperature was decreased to $70-75^{\circ} \mathrm{C}$ as recommended for corrosion protection (Table 1). With oxidized Zircaloy-2 (especially in the $70-75^{\circ} \mathrm{C}$ test), an induction period at the beginning of dissolution probably corresponded to the time required to penetrate the $\sim 0.1$ mil-thick oxide film. After this period, the dissolvent attacked the Zircaloy -2 and produced severe pitting; the dissolvent completely penetrated the metal after $2-7 \mathrm{hr}$ at boiling and $70-75^{\circ} \mathrm{C}$, respectively.

\section{TABLE 1}

Corrosion of 304L Stainless Steel

in $\mathrm{HF}-\mathrm{HNO}{ }_{3}-\mathrm{Al}\left(\mathrm{NO}_{3}\right)_{3}$ Solution

\section{Solution}

$2 \mathrm{M} \mathrm{HF}-1 \mathrm{M} \mathrm{HNO}_{3}$

$2 \mathrm{M} \mathrm{HF}-1 \mathrm{M} \mathrm{HNO}_{3}-1 \mathrm{M} \mathrm{Al}\left(\mathrm{NO}_{3}\right)_{3}$

$2 \mathrm{M} \mathrm{HF}-1 \mathrm{M} \mathrm{HNO}_{3}-$

$1 \mathrm{M} \mathrm{Al}\left(\mathrm{NO}_{3}\right)_{3}-0.1 \mathrm{M}\left(\mathrm{NH}_{4}\right)_{2} \mathrm{Cr}_{2} \mathrm{O}$,

\begin{tabular}{|c|c|c|}
\hline$\frac{(\mathrm{Corr} r}{50^{\circ} \mathrm{C}}$ & $\frac{\text { Rate }}{70^{\circ} \mathrm{C}}$ & $\frac{2 s / y r)^{0}}{90^{\circ} \mathrm{C}}$ \\
\hline$>5000$ & $>5000$ & $>5000$ \\
\hline 16 & 40 & 212 \\
\hline 2 & 4 & 22 \\
\hline
\end{tabular}

a. From Reference 1.

In accordance with the recommended Alniflex procedure, ${ }^{4}$ concentrated $\mathrm{HF}$ was added periodically to prevent precipitation of $\mathrm{ZrF}_{4}$ and $\mathrm{AlF}_{3}$. However, precipitates were recovered after each dissolution; the precipitation problems were therefore studied more thorough1y, as will be described later. 


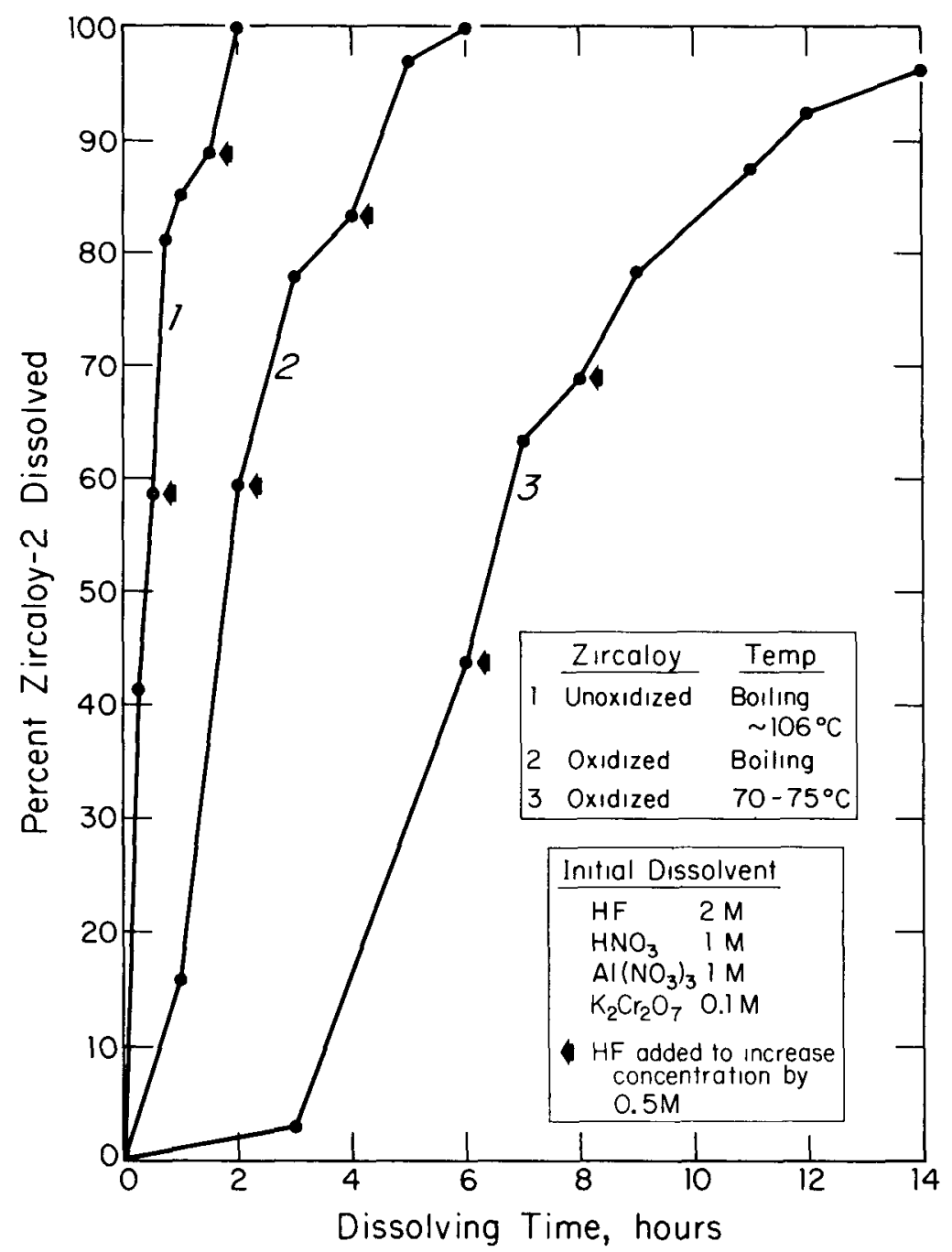

FIGURE 1 Alniflex Dissolution of Zircaloy-2 
Dissolution of Uranium Metal and

Uranium Dioxide in Alniflex Solution

Uranium metal and $\mathrm{UO}_{2}$ were dissolved in Alniflex solution to measure the rate of core dissolution during the cladding-penetration step. The dissolution rate increases after each $\mathrm{HF}$ addition, and significant quantities of both core materials will be dissolved during cladding penetration (Figure 2). Therefore, Alniflex claddingpenetration solution, possibly combined with the nitric acid dissolvent, must be processed by solvent extraction to recover uranium and plutonium.

Dissolution of uranium metal in $2 \mathrm{M} \mathrm{HF}-1 \mathrm{M} \mathrm{Al}\left(\mathrm{NO}_{3}\right)_{3}$ was investigated to determine the effect of omitting $\mathrm{HNO}_{3}$ and $\mathrm{K}_{2} \mathrm{Cr}_{2} \mathrm{O}_{7}$ from Alniflex solution. After $12 \mathrm{hr}$, the uranium pieces were coated with a green solid, presumably $\mathrm{UF}_{4}$. This was not observed in tests with Alniflex solution; the oxidizing agents ensure formation of $U(V I)$ in solution and prevent $\mathrm{UF}_{4}$ precipitation.

Dissolution tests with uranium metal and $\mathrm{UO}_{2}$ were conducted in boiling $10 \mathrm{M} \mathrm{HNO}_{3}$ for comparison with the results in Figure 2. Uranium metal dissolved completely in $5 \mathrm{hr}$, and the remainder of the $\mathrm{UO}_{2}$ pellet from the Alniflex dissolution test dissolved in $1 / 2 \mathrm{hr}$ in $\mathrm{HNO}_{3}$. Thus, as expected, the rate of core dissolution during the cladding-penetration step will be considerably lower than during the leaching step.

\section{Dissolution of Zircaloy-2-Clad Uranium Metal Fuel}

The penetrate-leach dissolution method was tested with a 4 -inch section of Zircaloy-2-clad uranium metal fuel tube $437 \mathrm{~g}$ total weight). The section was dissolved in $1200 \mathrm{ml}$ of Alniflex solution at $70^{\circ} \mathrm{C}$. The cladding was penetrated after 6 to $8 \mathrm{hr}$ of exposure to the solution (Figure 3 ); dissolution was continued for $18 \mathrm{hr}$ with $\mathrm{HF}$ additions after 8,12 , and $16 \mathrm{hr}$ of dissolving. After $18 \mathrm{hr}$, the cladding was heavily penetrated, and $245 \%$ of the uranium core had dissolved. Precipitate was noted after $8 \mathrm{hr}$, and continued precipitation of zirconium was indicated by erratic zirconium analyses for the remainder of the experiment (Figure 4). Solids $(42.5 \mathrm{~g})$ recovered after the experiment were predominantly $\mathrm{ZrF}_{4}$ (shown by spark source mass spectrometry). As discussed below, procedures were developed to prevent precipitation during subsequent experiments. 


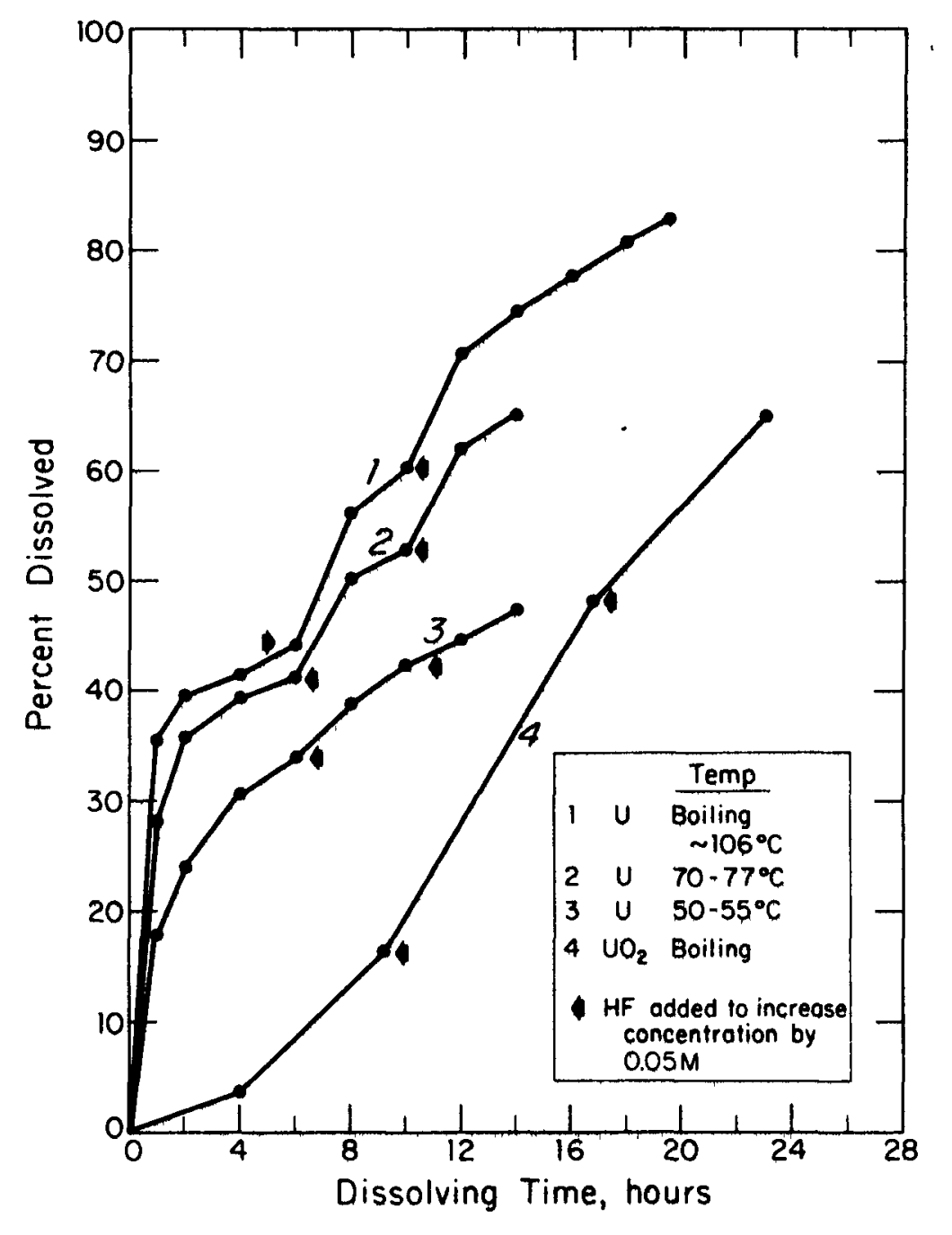

FIGURE 2 Alniflex Dissolution of Uranium Metal and Uranium Dioxide 

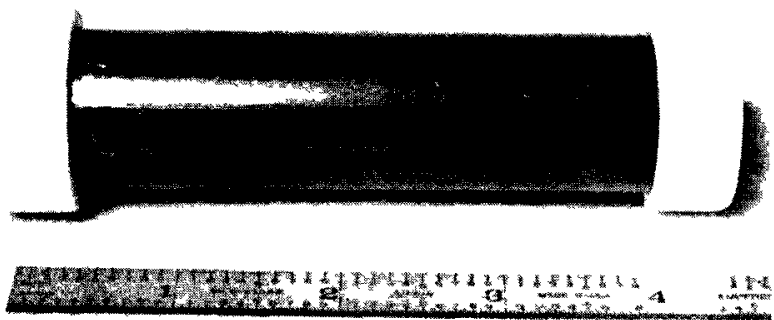

a. Before Dissolution
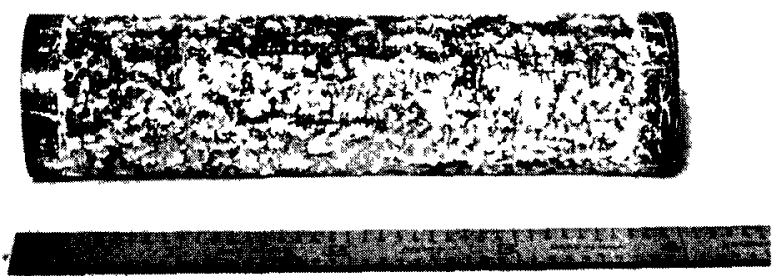

b. After $8 \mathrm{hr}$ in Alniflex

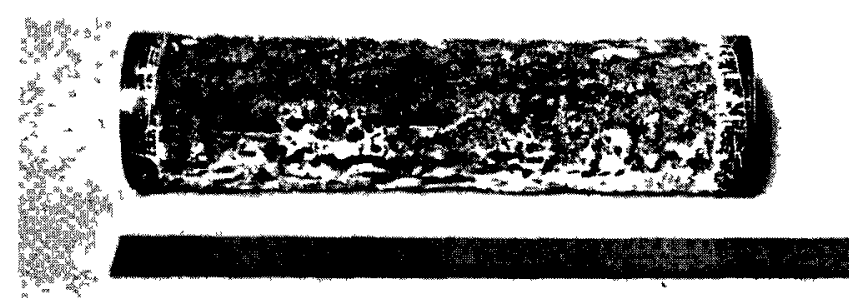

c. After $14 \mathrm{hr}$ in Alniflex
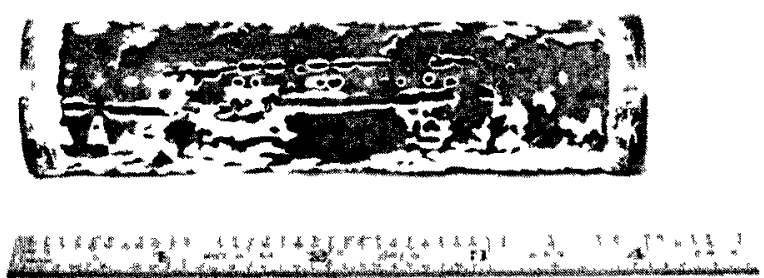

d. After $18 \mathrm{hr}$ in Alniflex

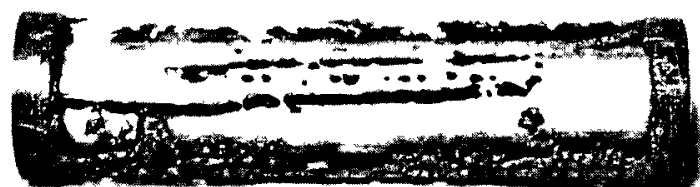

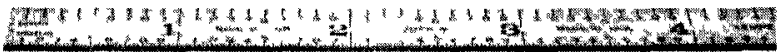 \\ e. After 36-hr $\mathrm{HNO}_{3}$ Leach}

FIGURE 3 Zircaloy-2-Clad Uranium Metal Fuel Piece During Penetrate-Leach Dissolution 


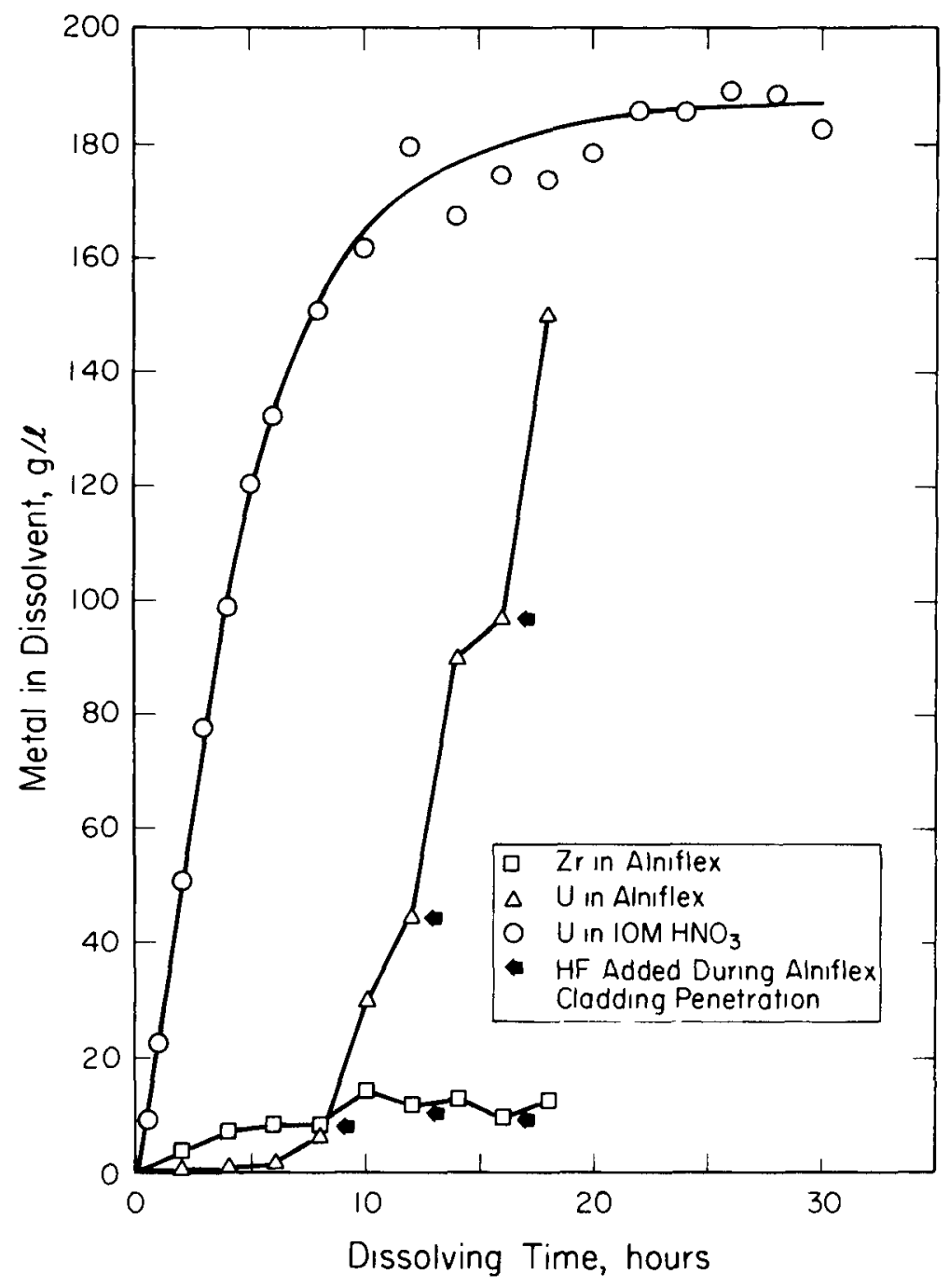

FIGURE 4 Penetrate-Leach Dissolution of Zircaloy-2-Clad Uranium Metal Fuel 
The cladding-penetration solution was removed, and the remainder of the fuel piece $(251 \mathrm{~g})$ was 1 eached with $500 \mathrm{~m} 1$ of $10 \mathrm{M} \mathrm{HNO}_{3}$ (Figure 4). After $10 \mathrm{hr},>80 \%$ of the uranium had been dissolved, but an additional $26 \mathrm{hr}$ was required for complete dissolution because the acid concentration had decreased to an ineffective level $(\sim 2.5 \mathrm{M})$. The spent cladding is shown in Figure 3. In another experiment with a similar portion of fue 1 , only $10 \mathrm{hr}$ was required for complete leaching of uranium when the $\mathrm{HNO}_{3}$ concentration was maintained near $10 \mathrm{M}$. These results suggest that leaching with two separate volumes of $10 \mathrm{M} \mathrm{HNO}_{3}$ is desirable to minimize dissolvent volume and to decrease the time required for complete dissolution.

\section{Precipitation During Alniflex Cladding Penetration}

Conditions for stability of Alniflex solutions against precipitation had been established during Alniflex development; ${ }^{4}$ total fluoride concentration was used as the basis. $\mathrm{AlF}_{3}$ precipitates if the total fluoride concentration is too high; too low a total fluoride concentration results in $\mathrm{ZrF}_{4}$ precipitation. The recommended procedure for avoiding precipitation consisted of dissolving the fuel with the initial Alniflex solution to $0.2 \mathrm{M} \mathrm{Zr}$ and then increasing the total fluoride content by $0.5 \mathrm{M}$ every $2 \mathrm{hr}$ until the desired maximum zirconium concentration ( $\sim 0.5 \mathrm{M}$ ) was obtained." However, periodic HF additions on a set time schedule during cladding penetration did not prevent precipitation (Experiments $A$ and $B$ in Table 2). Data summarized in Reference 10 indicated that the precipitation in Experiment $B$ was caused by low acidity. To correct this problem, $\mathrm{HNO}_{3}$ was added periodically in subsequent experiments to maintain the $\mathrm{H}^{+}$concentration $>1 \mathrm{M}$. A coating of white precipitate on the fuel pieces, often observed during weight loss measurements, was attributed to fluoride depletion near the fuel. To correct this, an air sparge was used in Experiments $C$ and $D$ to provide efficient mixing.

The major problem in preventing precipitation is determining the concentration of dissolved zirconium during the claddingpenetration step, so that the proper fluoride concentration can be maintained by HF additions. For processing fuel in a remotely operated facility, a remote sensing method is desirable. A test of such a method was conducted in Experiment D, in which the zirconium concentration was monitored by measuring the specific gravity and temperature of the dissolvent. The zirconium concentration was calculated from Equation 1:

$$
\begin{aligned}
\text { Specific gravity }= & 1.2297+\left(1.4844 \times 10^{-3}\right)(\mathrm{Zr}, \mathrm{g} / 1)- \\
& \left(7.2336 \times 10^{-4}\right)\left(\text { temperature, }{ }^{\circ} \mathrm{C}\right)
\end{aligned}
$$


TABLE 2

\begin{tabular}{|c|c|c|c|c|c|}
\hline $\begin{array}{l}\text { Experi- } \\
\text { ment }\end{array}$ & $\begin{array}{l}\text { Fuel } \\
\text { Piece, } \\
\text { g }\end{array}$ & $\begin{array}{l}\text { Procedures to Control } \\
\text { Precipitation }\end{array}$ & $\begin{array}{l}\text { Preoipi- } \\
\text { tate, } g\end{array}$ & $\begin{array}{l}\mathrm{Zr} / \mathrm{A} \mathrm{I}^{a} \\
\text { Ratio in } \\
\text { Precipitate }\end{array}$ & Cause of Precipitation \\
\hline A & 205 & $\begin{array}{l}\text { HF additions after } 6 \text {, } \\
8 \text {, and } 10 \text { hr; weight } \\
\text { loss measurements }\end{array}$ & 21.7 & 20 & Low HF concentration \\
\hline B & 437 & $\begin{array}{l}\text { HF additions after } 8 \text {, } \\
12 \text {, and } 16 \mathrm{hr} \text {; weight } \\
\text { loss measurements }\end{array}$ & 42.5 & 7.5 & Low $\mathrm{H}^{+}$concentration \\
\hline C & 302 & $\begin{array}{l}\mathrm{HF} \text { and } \mathrm{HNO}_{3} \text { additions; } \\
\text { agitation; weight loss } \\
\text { measurements }\end{array}$ & 21.0 & 980 & $\begin{array}{l}\text { Low HF concentration } \\
\text { (desired maximum } \mathrm{Zr} \\
\text { concentration was in- } \\
\text { advertently exceeded) }\end{array}$ \\
\hline D & 96 & $\begin{array}{l}\mathrm{HF} \text { and } \mathrm{HNO}_{3} \text { additions; } \\
\text { agitation; specific } \\
\text { gravity measurements; } \\
\text { weight loss measurement }\end{array}$ & $\begin{array}{l}0 \\
\mathbf{s}\end{array}$ & - & - \\
\hline
\end{tabular}

a. Uranium concentration of all precipitates was very low $(<0.1 \mathrm{wt} \%)$.

Equation 1 was derived from least-squares analysis of measured specific gravities of Alniflex solutions containing various concentrations of zirconium at 25 to $70^{\circ} \mathrm{C}$. Partial data are shown in Figure 5. Additions of $\mathrm{HF}$ and $\mathrm{HNO}_{3}$ based on calculated zirconium concentrations and the Alniflex stability relationships ${ }^{4}$ maintained a stable solution in Experiment $D$.

Measurement of zirconium concentration by specific gravity is complicated by variations in acidity and fluoride and uranium concentrations. As shown in Figure 5, varying fluoride concentrations between $2 \mathrm{M}$ and $3 \mathrm{M}$ does not measurably affect dissolvent specific gravity. However, changes in $\mathrm{HNO}_{3}$ concentration and in dissolution of uranium core both significantly affect dissolvent specific gravity. Direct measurement of these concentrations is desirable; if it is not possible, semiworks tests with each type of fuel to be processed should be made to develop a schedule of $\mathrm{HF}$ and $\mathrm{HNO}_{3}$ additions. In-line methods should enable control of solution stability.

Semiworks measurement of the total time required for the cladding-penetration step in each fuel is also desirable, because the time will vary with the cladding thickness and the thickness of the oxide coating on the cladding. " Uranium analyses of the Alniflex dissolvent and/or an $\mathrm{NO}_{2}$ monitor in the dissolver offgas line could be used to determine when the cladding is sufficiently penetrated to terminate the cladding-penetration step. 


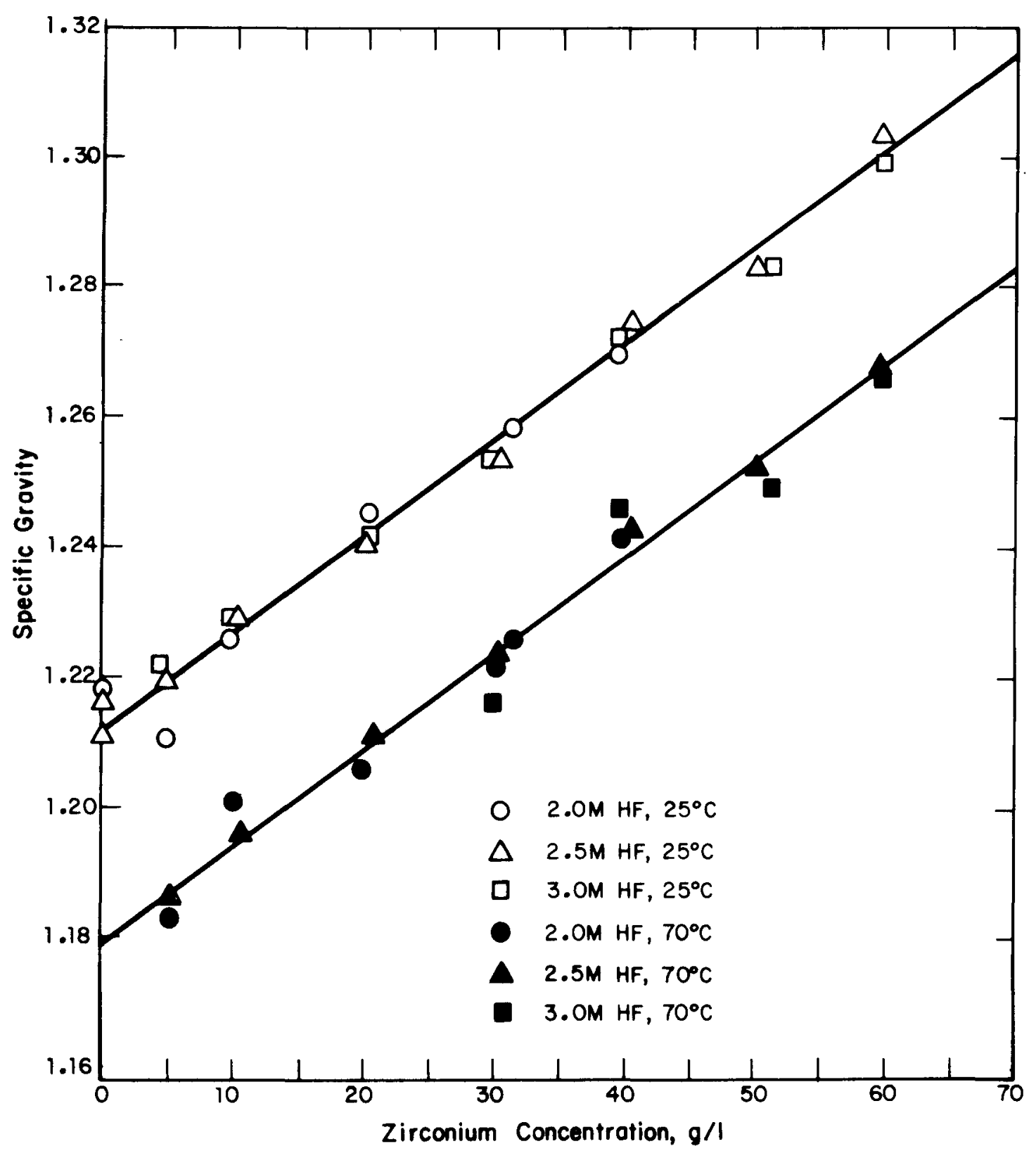

FIGURE 5 Specific Gravity of Alniflex Solutions 


\section{Preliminary Solvent Extraction Studies}

Previous study 10 of the recovery of uranium from zirconiumuranium alloy solutions used 3.5 vol \% TBP as extractant. However, the low-enriched uranium fuels that might be processed at SRP would be dissolved to higher uranium concentrations and would require a higher TBP concentration. Uranium distribution coefficients in 7.5 vol $\%$ TBP and 30 vol $\%$ TBP were measured for both Alniflex solution and a 2 to 1 blend of Alniflex solution and $\mathrm{HNO}_{3}$ leach solution. These distribution coefficients were used to calculate the range of process conditions over which efficient operation and adequate uranium recovery are obtained.

The results (Table 3 ) indicate complete recovery of uranium with $30 \%$ vol \% TBP* from both Alniflex and blended feed solutions.

TABLE 3

Extraction of Uranium from Alniflex and Blended $\mathrm{Alniflex}_{-} \mathrm{HNO}_{3}$ Solutions

\begin{tabular}{|c|c|c|c|c|}
\hline \multirow[b]{2}{*}{ TBP concentration, vol $\%$} & \multicolumn{2}{|c|}{ Alniflexa } & \multicolumn{2}{|c|}{$\begin{array}{l}\text { Blended } \\
\text { Alniflex-HNO }_{3}^{b}\end{array}$} \\
\hline & 30 & 7.5 & 30 & 7.5 \\
\hline \multicolumn{5}{|l|}{ Distribution coefficient } \\
\hline Extraction section & 22.7 & 0.638 & 1.73 & 0.147 \\
\hline Scrub section & $1.8^{\circ}$ & $0.70^{d}$ & $1.8^{c}$ & $0.70^{d}$ \\
\hline Number of extraction stages & 8 & 8 & 8 & 8 \\
\hline Number of scrub stages & 8 & 8 & 8 & 8 \\
\hline \multicolumn{5}{|l|}{ Relative flow } \\
\hline Aqueous feed & 1.0 & 1.0 & 1.0 & 1.0 \\
\hline Aqueous scrub & 0.17 & 0.55 & 0.5 & 0.55 \\
\hline Organic extractant & 0.83 & 5.0 & 2.5 & 5.0 \\
\hline Aqueous waste & 1.2 & 1.55 & 1.5 & 1.55 \\
\hline Organic product & 0.83 & 5.0 & 2.5 & 5.0 \\
\hline Calculated Recovery, : & 99.99 & 99.81 & 99.98 & 43.12 \\
\hline
\end{tabular}

a. Alniflex solution containing $68.7 \mathrm{~g} \mathrm{U} / 1$.

b. Blended solution containing $238 \mathrm{~g} \mathrm{U} / 1$.

c. Estimated for $3 \mathrm{M} \mathrm{HNO}_{3}$ as aqueous scrub. 11

d. Estimated for $4 \mathrm{M} \mathrm{HNO}_{3}$ as aqueous scrub. ${ }^{12}$

* Purex processing ( 30 vol $\%$ TBP) of Alniflex solutions with uranium concentrations as $10 \mathrm{w}$ as $80 \mathrm{~g} / 1$ would require either modifications to the Purex process or blending with dissolved $\mathrm{UO}_{3}$ to increase the uranium concentration. 
With $7.5 \%$ TBP, high extractant/feed flow ratios and low scrub flows were required for uranium recovery of $>99 \%$ from Alniflex solution containing $68.7 \mathrm{~g} \mathrm{U} / 1$. The uranium concentration in the blended solution, $238 \mathrm{~g} \mathrm{U} / 1$, is too high for adequate uranium recovery with 7.5 vol $\%$ TBP. These uranium concentrations are higher than may be allowable for some fuels because of nuclear safety considerations, and dilution before processing may also be considered.

Dilution of the Alniflex or blended feed with $\mathrm{Al}\left(\mathrm{NO}_{3}\right)_{3}$ (as permitted by solution stability requirements) before extraction with 7.5 vol $\%$ TBP would: (1) complex fluoride and decrease corrosion of stainless steel equipment and (2) dilute the uranium and allow higher recovery with less extreme extractant/feed flow ratios. Further tests are required to determine whether satisfactory plutonium recovery is possible with either 7.5 or 30 vol\% TBP, because significant Pu(IV)-fluoro complex forms in Alniflex solutions.

\section{Preliminary Waste Neutralization Studies}

Tests were conducted to determine compatibility of spent Alniflex solutions with SRP waste handling procedures. In most cases these solutions require evaporation before neutralization with $\mathrm{NaOH}$. Alniflex cladding-penetration solution from the solvent extraction tests were extracted several times with 30 vol $\%$ TBP to remove all uranium. This solution was neutralized by adding it to $50 \% \mathrm{NaOH}$. An excess of $\mathrm{NaOH}(\sim 1 \mathrm{M})$ was used above that required by stoichiometry for $\mathrm{H}+, \mathrm{Al}^{3+}$, and $\mathrm{Zr}^{4+}$. A thick, blue-green slurry was formed; solids did not settle overnight.

Conclusions were: (1) Alniflex waste must be neutralized without evaporation because the high fluoride concentration would corrode evaporators, and (2) the large volume of solids produced on neutralization ( 50 vol $\%$ after centrifugation) may present problems in pumping the waste to storage tanks.

\section{Behavior of $\mathrm{UZr}_{3}$ During Penetrate-Leach Dissolution}

Studies were conducted to assess the effect of $\mathrm{UZr}_{3}$ (epsilon phase of U-Zr system) on the safety of penetrate-leach processing of zirconium-clad uranium metal fuels. These fuels may contain $\mathrm{UZr}_{3}$, an unstable intermetallic compound known to react rapidly, sometimes explosively, under oxidizing conditions. $\mathrm{UZr}_{3}$ forms at the core-cladding interface during fabrication of zirconium-clad uranium metal and U-Zr alloy fuels, and may be formed in zirconiumclad $\mathrm{UO}_{2}$ fuels during fabrication and reactor operation at temperatures exceeding $350^{\circ} \mathrm{C} .{ }^{5,6}$ 
Pieces of Zircaloy-2-clad uranium metal fuel were examined with a scanning electron microscope before and after partial dissolution in Alniflex solution and in $10 \mathrm{M} \mathrm{HNO} \mathrm{H}_{3}$. Before dissolution, a thin layer of $\mathrm{UZr}_{3}$ was observed at the core-cladding interface or bond zone. During Alniflex dissolution of uranium metal fuel, the bond zone was attacked faster than the cladding or the core (Figure 6a). Uniform dissolution of the bond zone was indicated by smooth, even surfaces; there was no sign of fracturing of the bond zone layer. Thus, Alniflex dissolution of this fuel is safe because no mechanism was identified for accumulation of hazardous $\mathrm{UZr}_{3}$. Alniflex dissolution of zirconium-clad $\mathrm{UO}_{2}$ fuels should be safer still because of lower $\mathrm{UZr}_{3}$ content. However, this could not be tested because $\mathrm{UO}_{2}$ fuels containing $\mathrm{UZr}_{3}$ were not available.

During chemical dissolution in $\mathrm{HNO}_{3}$, the $\mathrm{UZr}_{3}$ layer of the bond zone did not dissolve or break into small pieces, but remained attached to the undissolved Zircaloy-2-cladding (Figure 6b). Therefore, $\mathrm{UZr}_{3}$ could be removed from the dissolver with spent cladding as in the shear-leach process. Penetrate-leach dissolution actually presents fewer safety problems than shear-leach processing because part of the $\mathrm{UZr}_{3}$ dissolves during cladding penetration. Further study is necessary to evaluate the safety of handling waste cladding with $\mathrm{UZr}_{3}$ present.
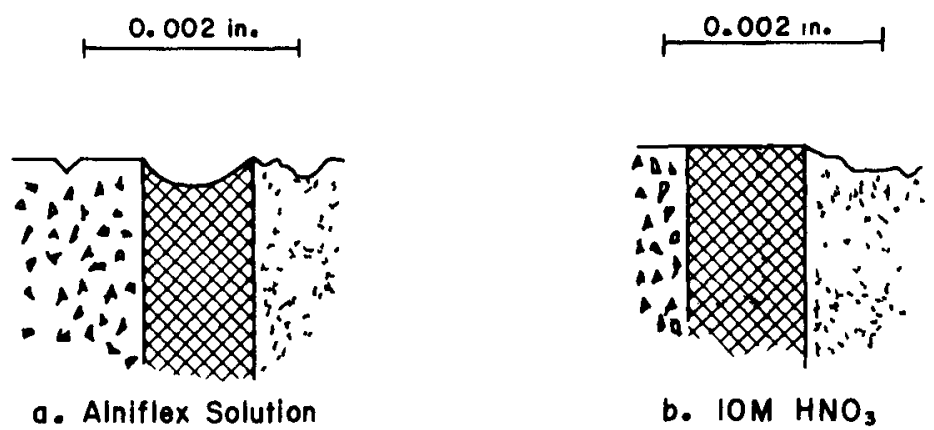

Bond Zone (UZ $\mathrm{r}_{3}$ )

Artad Zircaloy 2 Clodding

His Uranium Metol

FIGURE 6 Behavior of $\mathrm{UZr}_{3}$ During Penetrate-Leach Dissolution of Zircaloy-2-Clad Uranium Metal Fuel

\section{ACKNOWLEDGMENT}

The scanning electron microscope studies of $\mathrm{UZr}_{3}$ dissolution were conducted by $W$. N. Rankin. 


\section{REFERENCES}

1. P. W. Smith. The Zirflex Process Terminal Development Report. USAEC Report HW-65979, General Electric Company, Hanford Atomic Products Operation, Richland, WA (September 1960).

2. V. P. Caracciolo and A. A. Kishbaugh. Electrolytic Dissolver for Power Fuels. USAEC Report DP-896, E. I. du Pont de Nemours and Company, Savannah River Laboratory, Aiken, SC (October 1964).

3. B. C. Finney, B. A. Hannaford, G. A. West, and C. D. Watson. Shear-Leach Process: Semi-Continuous and Batch Leaching of Sheared, Unirradiated Stainless-Steel-Clad and Zircaloy-2-Clad $\mathrm{UO}_{2}$ and $\mathrm{UO}_{2}-\mathrm{ThO}_{2}$. USAEC Report ORNL-3984, Oak Ridge National Laboratory, Oak Ridge, TN (July 1969).

4. V. P. Caracciolo and F. G. Rust. "Alniflex Process for Dissolving Zirconium-Uranium Alloy in 304L Stainless Steel Vesse1s," Ind. Eng. Chem., Process Des. Dev. 5, 364 (1966).

5. W. W. Schulz, F. A. Scott, and E. E. Voiland. The Identification and Characterization of Explosive Residues Produced by Dissolution of Uranium-Zirconium AZZoys. USAEC Report HW-32410, General Electric Company, Hanford Atomic Products Operation, Richland, WA (November 1954).

6. M. W. Mallet, J. W. Droege, A. F. Gerds, and A. W. Lemmon, Jr. The Zirconium-Uranium Dioxide Reaction. USAEC Report BMI-1210, Battelle Memorial Institute, Columbus, OH (July 1957).

7. C. D. Hodgman (editor). Handbook of Chemistry and Physics, 42nd Edition. Chemical Rubber Publishing Co., Cleveland, OH (1961).

8. E. W. Baumann. "Trace Fluoride Determination with Specific Electrode." Anal. Chem. Acta 42, 127 (1968).

9. S. R. Nemeth. Metal Fuel Tube Manufacture. USAEC Report DP-976, E. I. du Pont de Nemours and Company, Savannah River Laboratory, Aiken, SC (July 1965).

10. H. E. Henry. Recovery of Uranium from Zirconium-Uranium AZloy. USAEC Report DP-826, E. I. du Pont de Nemours and Company, Savannah River Laboratory, Aiken, SC (May 1963).

11. J. W. Codding, W. 0. Haas, and F. K. Heumann. Equilibrium Data for Purex Systems. USAEC Report KAPL-602, Kno11s Atomic Power Laboratory, Schenectady, NY (November 1951; declassified February 1960).

12. M. C. Thompson, B. E. Murphree, and R. L. Shankle. EquiZibrium Distribution of Uranyl Nitrate Between Nitric Acid and 7.5 vol \% TBP. USERDA Report DP-1384, E. I. du Pont de Nemours and Company, Savannah River Laboratory, Aiken, SC (October 1975). 